\title{
OS DEFENSORES DO ESCRAVISMO NA IMPRENSA LUDOVICENSE
}

$(1881-1888)^{1}$

Marcos Aurélio Santos Pereira

(Graduado em História pela Universidade Estadual do Maranhão)

Resumo: Ao longo da escravidão no Brasil, a província do Maranhão foi uma das principais usuárias dessa mão-de-obra, sendo que, entre o final do século XVIII e as primeiras décadas do século XIX, com sua inserção na economia agro-exportadora e seu conseqüente e breve apogeu econômico, essa utilização se intensificou, ficando o Maranhão conhecido como um dos pilares dessa instituição servil no país. O presente trabalho constitui-se num estudo sobre as idéias contrárias à abolição do elemento servil no Maranhão através da imprensa diária de sua capital.

Palavras-chave: Escravistas. Imprensa. Maranhão

Abstract: As long as the slavery remained in Brazil, the province of Maranhão was one of the main users of this kind of labor, being that between the end of the XVIIIth century and the first decades of the XIXth century with its insertion in the agro-exporter economy and its consequent economy apogee, this use was intensified. Maranhão was know as one of the pillars this servile institution in the until. The present work consists in a study on the ideas contrary to the abolition of the servile condition in Maranhão through the daily press of its capital.

Key-words: Slave Holders. The Press. Maranhão.

\section{INTRODUÇÃO}

A discussão em torno das idéias contrárias ao fim da escravidão, através da imprensa periódica de São Luís, capital do Maranhão, é nosso objeto de estudo. Sabemos das dificuldades que envolvem tal análise, pois algumas indagações devem ser feitas a essa fonte, posto que, muitas vezes - em especial nesse período sobre o qual vamos nos debruçar, final do século XIX - possui uma escrita apaixonante sobre as causas que defendem e/ou atacam.

${ }^{1}$ Este artigo é parte da monografia de conclusão de curso de História, pela Universidade Estadual do Maranhão, A crise do elemento servil no "Baluarte da escravidão": um estudo do embate entre abolicionistas e escravistas em três grandes jornais de São Luís (1881-1888). 
Consideramos ainda que os periódicos, ao fazerem o registro da percepção que os homens de seu tempo tinham da realidade, constituem-se num importante material de análise para os historiadores, visto que se trata da reflexão de personagens que viveram e sentiram tal acontecimento, revelando ainda as situações mais diversas da sociedade, como seus usos e costumes e questões relativas à política e à economia.

Desta forma, analisaremos as idéias dos defensores da escravidão. Aqueles que, utilizando-se dos mais diferentes meios, procuraram prolongar o regime servil no país e, conseqüentemente, não aceitavam, em hipótese alguma, qualquer idéia abolicionista que viesse expropriá-los de suas "propriedades".

Nosso desejo consiste em estudar uma região que, apesar da construção de todos os mitos que a enalteciam, diante das outras províncias no século XIX, era, na verdade, reconhecida, em todo o império, como um dos pilares da escravidão no país, permanecendo escravista até o último momento de vigoramento do regime servil. Essa imagem, inclusive, era caricaturada em vários artigos de jornais de outras províncias do Brasil, que faziam representar a província maranhense como sendo sempre a mais atrelada ao escravismo, dentre todas as outras do Império brasileiro.

Assim, ao estudarmos, pela imprensa, as idéias dos que repudiavam a Abolição, chamamos atenção, ainda, para o fato de que, no jornal, há uma prática discursiva que sempre resulta de um jogo de forças entre várias partes, transformando-o, por isso, num meio de manipulação de interesses e de interferência no cotidiano social.

\section{“É O FIM DA LAVOURA": A ANARQUIA BATE À PORTA}

Nada causava mais indignação e temor aos defensores da escravidão, na Província maranhense, do que a idéia de perderem sua mão-de-obra servil na lavoura e, assim, vê-la destruída, somando-se a esse acontecimento a perda sem indenização. Esse pensamento era constante na elite agrária, visto acharem que o negro, uma vez liberto, não aceitaria mais tal trabalho por considerá-lo desprezível e indigno, que o homem livre nativo era preguiçoso e indolente e, da mesma forma, desprezava o trabalho manual e, por fim, consideravam a emigração européia impossível para esta parte do Império, devido às 
condições climáticas desfavoráveis, que faziam os imigrantes escolherem o Sul em detrimento do Norte do país (FARIA, 2004).

Essa aristocracia proprietária de escravos manteve-se irredutível, até o último momento, considerando qualquer defesa à emancipação dos escravos um "abolicionismo revolucionário", que deveria, a todo custo, ser repelido.

Para esse combate aos abolicionistas, os lavradores ${ }^{2}$ foram chamados para a organização e união, na criação de centros de amparo à lavoura e ao comércio, que pudessem defender seus interesses ${ }^{3}$. A exemplo de outras províncias, esses lavradores foram convocados para conferências, para irem à imprensa mostrarem sua indignação com o que eles achavam ser o preterimento do governo com sua classe, e esse apelo seria acima de tudo um sinal de alerta ao comércio e à lavoura da Província:

Diante da magna questão da actualidade, que tão intimamente se liga aos interesses destas duas classes importantíssimas, da nossa província, tem sido, se não censurável indifferença, ao menos um grande erro, a não formação de um centro, onde tão vitaes interesses sejam convenientemente deffendidos.

(...) Desejamos ver no norte imitado esse procedimento, que fosse igualmente promovida a creação desses Centros onde, pela discussão franca e sincera bem fundada e encaminhada, se mostrasse que não é com o silencio ou com a indifferença que olhamos para o futuro desta provincia em particular e do paiz em geral.

O commercio e a lavoura, unidos em um só pensamento, essas duas industrias tão poderosas e que são o mais certo elemento de propriedade do paiz, devem formar um partido, seu, exclusivamente seu, e affastados de quaesquer outros interesses partidarios, se ocuparem mais particularmente do que lhes diz respeito, do que possa ocorrer para o seu progresso, desenvolvimento e futuro independente (DIARIO DO MARANHÃO 29 de julho de 1884).

O alerta feito para a "magna questão da atualidade", na verdade, se constituía bem mais do que um simples alerta: era uma convocação para uma luta que se travava há algum tempo e que, na década de 80, do século XIX, tendia a se intensificar; por isso, o pedido de cautela, feito no artigo, na hora da discussão de tal questão, para que "os interesses vitais" dos proprietários de escravos fossem "convenientemente defendidos". Isto porque, para os defensores do regime servil, qualquer abolicionismo era considerado "terrorismo", levado a efeito por radicais que agiam, mais pelo "coração" e por seus ideais humanitários, do que pela razão de homens prudentes e sensatos.

\footnotetext{
2 Ricos proprietários que possuíam engenhos, fazendas e muitos escravos como parte de sua riqueza no século XIX.

${ }^{3}$ Sobre os clubes da Lavoura e Comércio vejamos: "Em nenhum momento [...] manifestaram seu apoio ao abolicionismo. Todas as representações desses [...] setores enviadas à Câmara são de repúdio ao movimento, acusado de ameaçar a ordem econômica e política" (MONTENEGRO, 1988, p. 39).
} 
No jornal O Paiz (14 agosto de 1884), vem expressa tal preocupação numa circular que a comissão do Centro Comercial e Agrícola dirigiu aos lavradores e negociantes do interior da Província, referindo-se ao projeto de lei que pretendia libertar os escravos com mais de 60 anos.

\begin{abstract}
O sentimento abolicionista, que se resumira até agora em votos descompassados de vaga ainda que inexcusavel philantrophia, avassala actualmente os poderes públicos e ameaça de golpe efficaz a propriedade, as instituições e a tranqüilidade do paiz que habitamos.

O projecto, offerecido modernamente pelo governo do Imperador á consideração do parlamento affecta radicalmente a instituição servil, sobre que repousa a fortuna publica.

... Essa complexa e afflictiva conjuctura, cujo horroroso desenlace será de prompto epilogado pela abolição violenta do elemento servil, precisa de ser conjurada pelos bons cidadãos e habitantes do paiz interessados em preservar da ruína os elementos conservadores do organismo social.

Só tendo por movel o do principio instictivo da conservação e salvação geral, promovem os creadores do "Centro Agrícola e Commercial do Maranhão" esta instituição, cujos artigos fundamentaes vos são agora presentes e cujo precípuo intuito é impedir á sombra da lei a propaganda da abolição violenta do elemento servil, o qual deve ser emancipado lenta e gradualmente, como convem aos interesses do commercio e lavoura, que representam as classes mais ordeiras, pacificas, abastadas e productoras do Brazil.
\end{abstract}

Assim, ao ameaçar a lavoura, a propaganda abolicionista, do ponto de vista dos escravistas, colocava em risco a segurança e a ordem de todo o país, pois seriam vários os setores a serem atingidos com o fim do trabalho escravo, causando um efeito dominó em diversos setores da sociedade, isto porque, para os defensores da escravidão, essa era uma questão socioeconômica tanto quanto o era política. Tal pensamento é expresso pelo deputado provincial Ricardo de Carvalho, no artigo publicado pelo jornal Pacotilha (10 de outubro de 1884, grifo nosso), evidenciando o temor e a preocupação dos proprietários de escravos ou seus representantes, com o porvir tenebroso que se aproximava, segundo seus temores, com o "Abolicionismo Revolucionário":

A abolição repentina do elemento servil é a grande questão nacional neste momento.

A abolição repentina do elemento servil é o pesadelo do commercio, e o cancro funesto que roerá as entranhas da provincia.

A abolição repentina do elemento servil é, por assim dizer, o objeto sobre o qual deve recahir a actividade da grande e patriótica opinião da provincia.

A abolição repentina do elemento servil é, finalmente o pleito supremo, de cuja solução depende o respeito à propriedade, a prosperidade, a integridade e o futuro do paiz.

A abolição repentina do elemento servil é, pois, uma questão de interesse geral da pátria uma questão política, uma questão de administração, uma questão economica...

É preciso que nos unamos todos, se queremos ser cidadãos e fazer a larga conquista da liberdade constitucional, de modo que tenhamos um dia a satisfação de ser livres cidadãos e não livres escravos.

Quando em um povo se escutam estrondosos vivas à liberdade, a anarchia está a porta, e a tyrania não vem distante. 
No artigo, observa-se a preocupação do autor com o que ele chama de "abolição repentina" que, em todo o texto, é lembrado para ser combatida. Ainda mais interessante é que ele utilizou alguns argumentos dos abolicionistas para combater a escravidão, só que logicamente, de modo inverso ${ }^{4}$. Apelos como: "respeito à integridade e o futuro do país", "ser cidadãos" ou "conquista da liberdade constitucional" são alguns exemplos.

Vale lembrar, ainda, que o autor do artigo, Ricardo de Carvalho, era um político conservador, que já havia sido deputado provincial e que, naquele ano (1884), era candidato a exercer um mandato na Câmara Geral do Império, local onde esse embate foi travado de forma mais intensa.

O temor de uma revolução de proporções inauditas também se revelava uma constante nos artigos dos defensores do prolongamento da escravidão, embora tal idéia parecesse pouco provável naquele momento. O exemplo estadunidense era sempre lembrad,o para que o Brasil não corresse o mesmo risco pois, nesse caso, vaticinavam que não teríamos a mesma "sorte" que teve os Estados Unidos e o esfacelamento do Império seria inevitável.

No caso dos Estados Unidos, o motivo de não ter sucumbido com o fim abrupto da escravidão, no entender dos escravistas, devia-se ao fato dessa nação, naquele momento, possuir uma indústria consolidada e ser uma nação rica, o que, no entanto, não impediu de ocorrer, neste país, "[...] a maior e a mais desastrosa guerra civil de que nos falla a história" (O PAIZ 28 de janeiro de 1881).

Esse exemplo era um espectro que fazia a elite proprietária de escravos, de todo o Império, a exemplo do Maranhão, estremecer só ao imaginar que pudesse vir a ocorre,r no país. Por isso, o alerta do senhor I. H de Berredo, no jornal O Paiz (28 de janeiro de 1881):

[...] Hoje é certo gosa a nação americana das inegaveis vantagens dos paizes livres, mas o quadro doloroso da reconstituição da primeira potencia de ambas as Americas foi uma amarga licção para os abolicionistas - as finanças do paiz ficarão n'um estado lastimoso, os campos destruidos, incendiadas as cidades, os homens sem moralidade, e, a não ser a virilidade da União Americana, o Estado teria desapparecido!

\footnotetext{
4 “Á medida que cresciam os ataques à escravidão, seus ideólogos e beneficiários procuraram defendê-la com as mesmas armas utilizadas por seus oponentes. Ou seja, adaptaram em proveito próprio os postulados e princípios do liberalismo [...]" (QUEIROZ, 1993, pp. 56-57).
} 
Rica, industriosa, com mais de trinta milhões de habitantes - quasi baquêa na lucta a União Americana - pobre, ignorante, sem industria com uma população insignificante, o Brasil baquêará de certo!

Ainda neste artigo, transcrito aqui apenas em parte, encontramos outro artifício bastante utilizado pelos escravocratas para combaterem o que chamavam de propaganda incendiária, que colocaria o país numa anarquia geral. Tal estratagema consistia em vilipendiar os principais líderes da causa abolicionista, como forma de torná-los indispostos perante a opinião pública. Um personagem que sofreu constantes ataques foi Joaquim Nabuco porque, para os senhores de escravos, longe de advogar a causa da emancipação, "[...] elle declama contra a escravidão por ambição e gloria, por vaidade somente, e mais para ser applaudido do estrangeiro, do que por verdadeiro amor a liberdade" (O PAIZ 28 de janeiro de 1881).

Ao proclamarem tal afirmação, os escravistas queriam mostrar à sociedade, em geral, que os abolicionistas envolviam-se nessa questão sobre o fim da escravidão por motivos de interesses pessoais, pela glória de serem reconhecidos no exterior e não por preocupação com o futuro do país. Assim, na luta entre abolicionistas e escravistas, estes procuravam neutralizar aqueles, caricaturando-os como interesseiros e tornando-os antipáticos ante a opinião pública geral.

Tal artimanha, no entanto, estava longe de sobrepor-se àquela que falava de terror, de dias tenebrosos, com derramamento de sangue, um verdadeiro cataclisma social, onde, primeiro, perder-se-ia a propriedade representada nos escravos e, logo após, o próprio lar e as grandes posses de terra seriam extorquidas, sofrendo, toda a nação, o colapso do anarquismo. Novamente é o jornal O Paiz (07 de maio de 1881) que traz expressa, da seguinte forma, essa temeridade:

[...] Devemos desconfiar destes pseudo liberaes, que, tratando de legislar, enxergão sempre nas mais graves questões sociaes somente o lado humanitario: são communistas que trazem ao seio da sociedade o veneno fatal das suas idêas.

Hoje, querem esbulhar-nos desta propriedade porque é deshumana, á manhã por caridade nos obrigarão a vestir os proletarios; depois lembrar-se-hão por equidade de distribuição da terra, e afinal levarão a nação com a sua mal entendida philantropia á anarchia, á dissolução.

Assim, crise da lavoura, anarquismo, violação de direitos constitucionais com o fim da propriedade escrava e, principalmente, o não pagamento de indenização por parte do 
governo àqueles que perderiam seus "bens" são elementos que, a todo instante, vinham à tona, na imprensa local, como motivos para não se querer o fim da escravidão ou, ao menos, que esta não fosse imediata. Ainda mais porque, aliada a todos esses fatores, existia uma crise econômica que, segundo os escravistas, levaria o país à catástrofe total, como veremos no artigo a seguir, do senhor I. H de Berredo, que parecia estar muito interessado na manutenção do regime servil, questão que lhe estava, ao que parece, tirando a tranqüilidade:

[...] Como nação possuidora de escravos, está o Brazil em condições especiaes, que de todo o ponto o inhibem de levar a effeito a emancipação sem previa indemnisação, porque todo o paiz vive exclusivamente de lavoura e esta é feita exclusivamente pelos escravos.

[...] Sendo sem contestação a lavoura a sua única fonte de riqueza, como é que poderá então o Brazil, d'um momento para o outro, abrir mão da escravidão sem indemnisação e nem tendo capitaes para attenuar os effeitos dolorosos do criminoso attentado contra o direito de propriedade?

Em taes circumstancias, não será só a lavoura, convençamos-nos d'isto, que há de soffrer os terríveis effeitos da espantosa crise social: é o commercio, é o funcionalismo é o paiz inteiro, representado por todas as suas classes, que a súbita desorganisação do trabalho, a falta de capitaes e finalmente a anarchia reduzirão a maior extremidade. (O PAIZ 28 de dezembro de 1881)

Como podemos observar, era intenso o apelo feito aos proprietários de escravos para que se organizassem e pudessem, de todas as formas e nos mais variados setores da sociedade, combater os abolicionistas. Esse chamado, na verdade, era feito a toda a sociedade, visto ser um colapso, em proporções globais, o temor dos escravistas, causado pela crise da lavoura, em conseqüência do fim do cativeiro, e que, nessa hierarquia de acontecimentos, levaria o País à ruína econômica e a uma revolução social, que o dissolveria ${ }^{5}$.

Toda essa cautela devia-se ao temor que as elites dominantes no Brasil sempre tiveram de uma abolição precedida ou sucedida por um acontecimento violento, como a guerra civil ocorrida nos EUA e sempre presente na memória dessa elite. Devido a isso, a classe dominante procurará desestimular a discussão nas ruas - vendo-a de forma pejorativa - e levá-la para o Parlamento, para que seja decidida na mais completa ordem, sem a euforia das massas e, principalmente, sem a participação intensa dos próprios cativos. “Assim, o Parlamento se colocava como ‘saneador’ das agitações das ruas. Uma abolição

\footnotetext{
5 "Durante todo o período em que perdurou a escravidão, os defensores da ordem estabelecida invocavam o direito de propriedade, acenaram com os perigos da emancipação e ameaças de carnificinas terríveis, o atraso, a miséria, a perturbação da ordem pública, e da vida econômica do país.” (COSTA, 1989, p. 337).
} 
feita pela ação parlamentar, feita 'por cima', mais seguramente neutralizaria a mobilização social, evitaria conflitos [...]" (MENDONÇA, 1999, p.102).

$\mathrm{Na}$ busca pela defesa dos seus interesses, os proprietários de escravos travaram mais um embate com os abolicionistas, agora no Parlamento, através de seus representantes, escolhidos entre aqueles cujas idéias fossem ao encontro de seus anseios e que estivessem dispostos a defender, peremptoriamente, a continuidade do regime escravista no País.

\section{OS ESCRAVISTAS E AS ELEIÇÕES}

Sabendo que, principalmente na década de 1880, o Parlamento Brasileiro constituiu-se num campo fértil para o embate entre abolicionistas e escravistas - em especial para evitar as agitações das ruas ${ }^{6}$ - essa análise das eleições mostra-se ainda mais interessante, principalmente ao sabermos que a Província maranhense fora representada por parlamentares de destaque no plano nacional.

Estes parlamentares eram influentes, nas discussões travadas no momento, além de serem reconhecidamente grandes oradores, com destaque para a figura do deputado Augusto Olympio Gomes de Castro, político conservador e ferrenho adversário dos abolicionistas, embora o próprio não se considerasse um antiabolicionista, como fica sugerido neste comentário. "O illustre parlamentar não é um escravocrato, porque como eloquentemente disse, ninguém neste paiz quer ligar seu destino ao da escravidão [...] reprova é este principio de não indemnisação, principio [...] que tira a paz e a tranqüilidade á nós lavradores" (DIARIO DO MARANHÃO, 30 de julho de 1884).

Assim, o debate político a ser travado, agora, embora tenha o Parlamento como arena principal terá, contraditoriamente, características extra-partidárias pois, para preservarem seus interesses, os proprietários de escravos pouco se importavam com as concepções de partido de seus representantes, porque,-lhes interessava era que esses "abolicionistas que vivem do thesouro devem ser repelidos do seio da representação nacional” (O PAIZ, 28 de janeiro de 1881).

\footnotetext{
6 "O movimento estava no Parlamento porque estava fora dele, e a recíproca também era verdadeira: uma questão de opinião transformada em instrumento de ação política, e uma questão política que atuava sobre a opinião púbica." (COSTA, 1989, p. 403).
} 
$\mathrm{O}$ apelo era de tal ênfase que, nesse mesmo artigo, ao falar de Joaquim Serra, considerado um dos vultos abolicionistas, deputado na Câmara Geral, representando a Província maranhense, o autor pediu, imperativamente, que os maranhenses cassassem seu “[...] mandato para a vindoura legislatura que elle cava a ruína da pátria”.

Essa indiferença para com o partido a que o candidato pertencia podia ser vista como uma ausência de ideologia partidária no Brasil da época imperial ${ }^{7}$. Com uma mentalidade ainda fortemente colonial, o que existia eram representantes de segmentos específicos da sociedade, que tentavam legislar de acordo com os interesses de seus representados. Por isso, o que importava aos escravistas era que seus anseios fossem atendidos, até porque "[...] não tendo precedentes históricos, não ha razão de ser nas denominações dos partidos - conservador e liberal - por pretenderem os sectarios destes partidos políticos a mesma cousa [...] todos chegam aos mesmos fins" (O PAIZ, 26 de outubro de 1881).

Vale ressaltar, ainda, que os abolicionistas, também, utilizaram-se do mesmo artifício supra-partidário para escolher seus representantes.

Assim, atendendo aos apelos da opinião pública, para que expusessem seus programas políticos, vários candidatos a cargos legislativos foram à imprensa, atender a esses "convites" e, dessa forma, mostravam suas idéias sobre os assuntos em voga. Expunham, para a sociedade em geral, de que lado estavam na questão do elemento servil e, ainda, revelavam que essa era uma discussão que a população, ou parte dela, estava atenta para seu desenrolar; por isso, exigia-se posicionamento dos candidatos.

Analisemos o exemplo do artigo de Antonio Henriques Leal, grande escritor maranhense, que se "imortalizou" e "imortalizou" a muitos, com sua obra O Pantheon Maranhense, traçando a biografia dos grandes vultos das letras, no Maranhão da primeira metade do século XIX. Candidato a uma vaga na Câmara vitalícia do Império (Senado), aberta com a morte de Cândido Mendes, em $1881^{8}$, Henriques Leal foi um dos que expôs suas idéias na imprensa e, conseqüentemente, disse o que a classe dominante maranhense,

\footnotetext{
${ }^{7}$ Apesar de apresentarem opiniões e interesses que os diferenciavam, os partidos monárquicos (liberal e conservador) no tocante à escravidão, tinham posturas semelhantes. Para saber mais sobre as divergências de projetos e composição dos partidos Ver. CARVALHO, José Murilo de. A Construção da ordem: a elite política imperial. Teatro de sombras: a política imperial. Rio de Janeiro: Civilização Brasileira, 2003.

${ }^{8}$ Seria composta uma lista tríplice, e caberia ao imperador validar ou não o nome do primeiro mais votado. A lista, na ordem dos mais votados, foi a seguinte: Felipe Franco de Sá (escolhido), Augusto Olympio Gomes de Castro e José da Silva Maia.
} 
em especial a elite agrária, queria ouvir, naquele momento. Dessa maneira, assim se dirigiu ao corpo eleitoral da Província, no jornal Diário do Maranhão (23 de setembro de 1881, grifo nosso):

Somos d'aquelles que entendem - e creio que deste parecer são todos - que a escravidão é um mal, é uma nodoa que nos tem maculado desde os tempos coloniaes e ainda perdura, e é ainda mais - um crime que nos incumbi expiar, fazendo-o desapparecer nos nossos costumes, como instrumento de trabalho. Mas quando e de que modo? Lentamente respeitando o direito de propriedade e indemnisando os possuidores de escravos...

Não preciptemos o paiz no abysmo que lhe procuram cavar imprudentes enthusiasmos de uma philosophia piedosa, mas irreflectida.

Em vez de taes propagandas tão abnóxias ao futuro da pátria, melhor fôra que todos unidos e constituindo uma só força fundássemos associações manumissoras, e cogitássemos de auxiliar a lavoura, reerguendo-lhe o credito, introduzindo novas culturas attrhaindo braços validos de outras nacionalidades...

Observamos no artigo acima - ao todo foram encontrados sete programas políticos - o jogo eleitoreiro daqueles que pretendiam agradar ambas as partes envolvidas na querela pelo fim da escravidão. Daí, todos se dizerem favoráveis à idéia, embora, em seus projetos, nada devesse ser feito, já que entendiam que a "benemérita Lei Rio Branco" era suficiente para esse fim. A preocupação com os proprietários de escravos, certamente, a classe de maior peso nas eleições, era constante, inclusive, fazia-se apelos, para que, se a escravidão fosse abolida, que se olhasse com humanidade o proprietário e sua família, não esquecendo a sempre citada indenização a ser paga aos "pobres" senhores da exploração do trabalho escravo.

Além disso, o que nos chamou a atenção, foi Henriques Leal pedir para que cessassem "as propagandas abnóxias ao futuro da pátria", em nome da criação de associações manumissores para que, essas sim, libertassem os escravos, de forma lenta e gradual. $\mathrm{Na}$ verdade, tais associações e o próprio governo, através do fundo de emancipação, ${ }^{9}$ criado pela "Lei Rio Branco", em 1871, vinham libertando os escravos, de forma tão lenta, que "[...] num importante discurso proferido pelo Sr. Ottoni no senado, lemos que sua excellencia provou que, no progresso em que vamos executando a lei de 28 de setembro, o verdadeiro emancipador é a morte" (O PAIZ ,19 de julho de 1884).

\footnotetext{
${ }^{9}$ Fundo criado pela Lei de 28 de setembro de 1871 (Rio Branco) com o fim de libertar determinado número de escravos através de cotas mensais distribuídas pelo governo central às províncias
} 
Isto porque, segundo o mesmo artigo, desde 1871, teriam morrido cerca de meio milhão de escravos, enquanto que, no mesmo período, através do fundo de emancipação, o Estado emancipara apenas 20.000 (vinte mil).

Ao iniciar o ano de 1884, houve um momento de longos e acalorados debates sobre o destino do elemento servil. Era o período do gabinete do Conselheiro e Senador Dantas, que pretendia elaborar um projeto de libertação, sem indenização dos escravos maiores de 60 anos. As reações, na Província maranhense, vieram de todas as direções e a pouca receptividade ao projeto, em especial no campo, era visível, porque "[...] nem as leis de 1830 ou de 1850 , nem a libertação do ventre representavam medidas que tirassem escravos do domínio de senhores. A libertação dos sexagenários, essa sim [...] interviria diretamente na relação de um determinado escravo com seu respectivo senhor" (MENDONÇA, 1999, p.105) ${ }^{10}$.

Tendo a Câmara Geral, nesse mesmo ano, tendo sido dissolvida pelo Imperador D. Pedro II, por ter-se indisposto com o gabinete Dantas, devido ao projeto supracitado, novas eleições foram convocadas para uma nova legislatura. Essas eleições, realizadas no Império, em dezembro de 1884, em consequiência da dissolução da Assembléia, não foram eleições comuns, pois representaram uma grande consulta à Nação ${ }^{11}$.

Sendo assim, nesse momento, uma verdadeira avalanche de artigos proliferou na imprensa maranhense, mostrando todo o interesse dos proprietários de escravos do Maranhão que, em momento algum, pensaram em abrir mão de suas propriedades. Tais artigos revelam, também, que o grande temor desses proprietários, com relação ao projeto de libertação dos escravos, era que, se naquele momento, os beneficiários eram os escravos maiores de 60 anos, “[...] quem nos pode garantir que amanhã este não se estenderá aos de 20 e 30 annos?” (DIARIO DO MARANHÃO 30 de julho de 1884, grifo nosso).

Novamente, os candidatos foram "convidados" a expor seus programas, suas idéias e, principalmente, seu posicionamento diante do projeto sobre o elemento servil mas, agora, com um diferencial em relação às eleições de 1881, pois, se os que disputaram o

\footnotetext{
${ }^{10}$ Este argumento refere-se especialmente ao direito de propriedade do senhor.

11 "As eleições a serem realizadas no império a $1^{\circ}$ de dezembro de 1884 , em conseqüência da dissolução da Assembléia solicitada por Dantas ao Imperador não eram eleições comuns, pois representavam no fundo uma consulta feita pelo governo à nação sobre a delicada questão do elemento servil.” (GRAF, 1981, p. 131).
} 
senado, naquela eleição, pediram votos a todos os eleitores maranhenses, em 1884, o País já havia passado por uma reforma eleitoral que mudara as regras do processo ${ }^{12}$.

Com essa reforma, as eleições passaram a ser distritais, ou seja, as províncias foram divididas em distritos eleitorais e os candidatos concorreriam por seus respectivos distritos, recebendo votos apenas destes. O Maranhão, na ocasião, ficou dividido em 6 (seis) distritos ${ }^{13}$.

Vejamos, agora, a cobrança feita ao candidato Costa Rodrigues, por um eleitor identificado como sendo um lavrador, do seu respectivo distrito, sobre como procederia a respeito da questão do elemento servil, caso fosse eleito. Nesse caso, foram quatro missivas dirigidas ao candidato, interrogando-o sobre seu posicionamento:

\begin{abstract}
Ainda não tivemos o prazer de ler um só artigo vosso, de ver na praça popular no meetings levar ao seio das massas a palavra electrizadora dos tribunaes da liberdade.

Ora exm. sr. o $3^{\circ}$ districto é o mais agrícola da província e portanto o mais interessado na resolução da questão do elemento servil. Accrescente ainda que é elle hoje representado pelo sr. Gomes de Castro que alem de seus dotes oratórios, de seu vasto talento, tem sobre esta questão idéias conhecidas, expostas de modo brilhante em notáveis dicursos que despertão tanto enthusiasmo, pois na sua pêssoa se encarnou a nossa lavoura com as suas aspirações de probidade política.

Hesitamos em saber exm. sr. qual o vosso modo de pensar sobre a questão elemento servil... v. exc. apóia este projecto?

Mas o projecto do conselheiro Dantas não tem o apoio da lavoura. Primeiramente por que está n'elle consagrado o principio querido dos mais audases abolicionistas - a libertação sem indemnisação.

Decidi pois, v. exc. sr. Apontais o projecto abolicionista? A lavoura não vos dará o voto. Combateis este projecto? Mas é preciso dizel-o para que o partido salino saiba que não poderá contar com o vosso apoio e recusar também d'elle. Em todo caso queremos saber vossa opinião. (DIARIO DO MARANHÃO, 30 julho de 1884, grifo nosso)
\end{abstract}

O tom intimidador desse artigo será encontrado em quase todos os outros, pois, segundo os interessados que tinham poder de pressão, com base no voto, “[...] a nossa província é vivamente interessada nesta questão abolicionista, porque a sua prosperidade ainda na maxima parte depende da lavoura e esta infelizmente está confiada a braços escravos” (O PAIZ, 04 de agosto de 1884, grifo nosso). Essa afirmação nos faz entender o porquê do autor do artigo, intitulado "Um lavrador" exigir um posicionamento claro do

\footnotetext{
${ }^{12}$ A reforma eleitora de 1884, conhecida como Lei Saraiva, aboliu o voto indireto e adotou novamente o sistema de distritos. (NICOLAU, 2002, p. 22).

${ }^{13} \mathrm{O} 1^{\circ}$ distrito era formado por São Luís, Paço do Lumiar, Rosário, Icatú, Miritiba e Anajatuba / o $2^{\circ}$ distrito formado por Alcântara, Guimarães, Cururupu, Turiaçu, Santa Helena e Pinheiro / o $3^{\circ}$ distrito formado por Viana, Monção, Penalva, Baixo-Mearim, Arari, São Bento, São Vicente Ferrer, São Luiz Gonzaga e Coroatá / o $4^{\circ}$ distrito formado por Itapecurú-Mirim, Vargem Grande, Barreirinhas, São Bernardo, Brejo, Buriti / o $5^{\circ}$ distrito formado por Caxias, São José dos Matões, Codó e Passagem Franca / o $6^{\circ}$ distrito formado por Pastos Bons, São Felix de Balsas, Barra do Corda, Chapada, Carolina, Riachão e Imperatriz. (O PAIZ, 15 de junho de 1883).
} 
candidato Costa Rodrigues, ainda mais porque este queria candidatar-se pelo $3^{\circ}$ Distrito, que era "o mais agrícola da Província" e, por conseguinte, uma das regiões que detinha maior número de mão-de-obra escrava (ver Tabela 1).

\section{TABELA 1}

População escrava do Maranhão por distritos em 1886

\begin{tabular}{|c|c|c|}
\hline Distritos & $\mathrm{N}^{\mathrm{o}}$ de escravos & $\%$ \\
\hline $1^{\circ}$ distrito & 9379 & 15,79 \\
\hline $2^{\mathrm{o}}$ “ & 12260 & 20,64 \\
\hline $3^{\mathrm{o}}$ “ & 16235 & 27,33 \\
\hline $4^{\mathrm{o}}$ “ & 4727 & 07,95 \\
\hline $5^{\mathrm{o}}$ “ & 12907 & 21,73 \\
\hline $6^{\circ}$ “ & 3882 & 06,53 \\
\hline Total & $59.390^{*}$ & $100 \%$ \\
\hline
\end{tabular}

Fonte: jornal O PAIZ dos dias 15 de junho de 1883 e 02 de julho de 1886 (Biblioteca Pública Benedito Leite). * no jornal o total com o somatório dos escravos por município é de 60.327 .

Como ficou explícito, no último artigo, era grande a pressão sobre aqueles que se dispusessem a disputar uma vaga na Câmara Geral do Império, porque, sob a menor suspeita de ser um candidato simpático ao projeto Dantas, os proprietários de escravos estavam alertas para a reação, e esta consistia numa grande campanha para que “[...] sòmente sejam eleitos candidatos anti-abolicionistas sobre cujo puritanismo, firmeza e energia não paire a menor duvida, nem seja necessária qualquer explicação" (O PAIZ 22 de setembro de 1884, grifo nosso). O voto foi o melhor meio que os lavradores, principalmente, encontraram para combater o que chamavam de "ministério abolicionista" e que pedia consistentemente um eleitor:

Já não ha que duvidar!

O ministério se apresenta francamente abolicionista e appella para a nação!

O que cumpre fazer?

O que nos cumpre é demonstrar nas urnas que ainda appellamos para os meios da lei, da ordem e da paz, enquanto a filaucia de um poder, que se creou e cresceu fora da lei fundamental, nós não obriga aos extremos da energia de um povo que é, e que quer permanecer livre e respeitado em seus direitos.

Procuremos salvar a nação emquanto é tempo.

A questão não é de theorias e doutrinas políticas; é de vida ou morte para a nação. 


\begin{abstract}
Atacado e ferido o direito de propriedade, e acceito e sanccionado esse attentado por uma eleição popular, onde irá parar a acção destruidora de um governo irreflectido e temerário?!

São bellas e christãs as doutrinas da liberdade, mas não podem as nações sanccional-as quando pereclitão os proprios interesses de sua exstencia.

O projecto Dantas é o precursor de uma liquidação, e ai do paiz que entra nas sombras do desespero e da fome!

(O PAIZ 25 de setembro de 1884, grifo nosso).
\end{abstract}

Colocando a questão como sendo de interesse vital para a segurança e prosperidade da Província, os defensores do escravismo, ao mesmo tempo em que procuravam despertar sentimentos patrióticos nos eleitores, direcionavam sua munição para amedrontar os candidatos simpatizantes ao projeto e contrários aos interesses do distrito que queriam representar. Foi o que parece ter ocorrido com o candidato Costa Rodrigues, já que, após aquele primeiro artigo aqui analisado, em que ele era "convidado" a dizer se era a favor ou não do projeto Dantas, encontramos outro artigo no qual ele declara ter abandonado a candidatura pelo $3^{\circ}$ Distrito, o mais agrícola da Província, e que candidatarse-ia pelo $4^{\circ}$, estando, por isso mesmo, ironicamente agradecido ao lavrador do Alto Mearim, responsável pelas missivas ${ }^{14}$. Assim, no jornal O Paiz (14 de agosto de 1884) temos:

\begin{abstract}
Primeiro que tudo permitta-me V. Exc. que lhe dê um abraço á portugueza e felicitações á franceza pela sua louvável resolução de abandonar o terceiro districto e ir pedir ao quarto a gloria de represental-o no parlamento nacional. Parece que calaram no espírito as considerações que expendi nas minhas cartas anteriores. V. Exc. comprehendeu perfeitamente que não era facil tarefa substituir no parlamento um vulto da estatura do Sr. Gomes de Castro, principalmente agora que o orador conquistou novos e brilhantes [ilegível] na defesa dos interesses desta provincia seriamente compromettidos com a leviana e imprudente agitação abolicionista.

Em todo o caso, podemos dizer a V. Exc. o que o grande Mirabeau dizia ao abbade Sieyés - o silencio de V. Exc. é uma calamidade publica.

Sei que V. Exc. é um homem ocupado, não tem tempo para responder a um pobre lavrador... Vou pois fazer-vos uma proposta - se V. Exc. conserva-se calado, é que acceita in totum as ideias contidas no projecto do conselheiro Dantas, eleito irá no parlamento prestar á causa abolicionista o concurso de seu voto e de sua palavra. Quem cala consente.

Queira desculpar, Exm. Sr. a impertinencia d'estas quatro cartas.
\end{abstract}

Ao que parece, um dos poucos políticos, a quem essa pressão parecia não ser necessária, era o sempre citado e exaltado, principalmente pelos lavradores, Augusto Olympio Gomes de Castro, pois, como já comentamos, era um político bastante experiente

\footnotetext{
${ }^{14}$ Segundo a informação do jornal “O Paiz” de 14.08.1884, esse eleitor escreveu quatro cartas ao Dr. Costa Rodrigues, no entanto, só foram encontradas duas cartas, que utilizamos nesse trabalho.
} 
e influente e que, de acordo com Ferreira (2004, p.209), "Como Silva Maia e Vieira da Silva ${ }^{15}$ estavam em idade avançada, aos poucos Gomes de Castro acabou ocupando parte do espaço político de ambos, tornando-se a principal liderança do partido e da província”.

Dentro ou fora da Província, esse político estava sempre a postos para defender os interesses dos proprietários de escravos, como afirma "Um maranhense", no Diário do Maranhão (16 de setembro de 1884):

[...] Quem acompanhou os debates da actual legislatura sabe perfeitamente que glorias o sr. Gomes de Castro conquistou na tribuna, que serviços sua palavra sempre escutada com respeitosa attenção prestou á causa publica e especialmente a sua terra natal. A primeira vez que s. exc. fallou na legislatura que acaba de ser dissolvida foi para levantar um solemne e energico protesto contra uma asserção injusta á nossa probidade emittida pelo sr. Martinho de Campos. Não tolerou o animo altivo do sr. Gomes de Castro semelhante offensa e então a sua palavra vibrante, enérgica, nervosa e apaixonada vingou os créditos da nossa provincia no dicscurso o mais applaudido que a câmara ouvio.

[...] Porem para nós o maior mérito de s. exc. foi a sua franca e decidida opposição ao projecto abolicionista.

O interessante, nesse artigo, é que a "asserção injusta à nossa probidade", que o texto diz não ter tolerado Gomes de Castro, foi a afirmação feita pelo senador mineiro, Martinho de Campos, de que todas as Províncias do norte do Império brasileiro eram abolicionistas, sem exceção. Isto, segundo o parlamentar maranhense, era um insulto a uma província essencialmente agrícola, como a do Maranhão, cujo argumento "difamatório" o "ilustre parlamentar" procurou prontamente rebater. Na continuidade do artigo, foram citados, ainda, outros dois discursos de Gomes de Castro sobre essa questão, onde ele traduziu perfeitamente “[...] a opinião do commercio e da lavoura d'esta província”.

Outra tática que os senhores de escravos trabalharam bastante, durante as eleições, foi demonstrar aos eleitores que, sem o braço escravo, o prejuízo para a Província era incalculável, isto porque a lavoura ressentir-se-ia de braços para substituir o braço cativo, visto não ser possível contar com o homem livre, nativo, nem com a imigração européia, inexistente nestas plagas, o que fazia crer que, dias de calamidade viriam, por falta dessa possível reposição. Por isso, independente de ser liberal ou conservador, como já dissemos, os lavradores pediam aos eleitores que fossem contrários ao antiprojeto Dantas, para que a lavoura pudesse ainda respirar e um possível progresso fosse alcançado nesta

\footnotetext{
${ }^{15}$ Líderes do partido Conservador no Maranhão com os quais Gomes de Castro provocou uma cisão partidária em 1879.
} 
terra, onde o escravo parecia ser, ainda, a maior fonte de riqueza, pelo menos, era o que pensava o cidadão "Cincinatus" que, no Diário do Maranhão (04 de setembro de 1884, grifo nosso), expressa, assim, tal preocupação:

O prejuízo que trará consigo a inopportuna reforma cahirá [...] principalmente, de modo mais pesado e assustador, sobre a lavoura e o commercio. Estas[...] não podem nas actuaes circunstancias soffrer um golpe tão profundo como o querem dar os abolicionistas tendo á frente o sr. presidente do conselho de ministros.

O obscuro escriptor d'estas linhas já percorreu os districtos mais agrícolas da província, já visitou os principaes engenhos de Vianna, S. Bento, Pericuman e Rosário. Em todos elles procurou debalde livre. E os lavradores una você lhe informavam que o homem livre morador nas visinhanças do engenho só os procuravam para pedir remédios ou dinheiro emprestado.

(...) A lavoura pode ainda sentir a propaganda revolucionaria. Basta não votar em candidatos abolicionistas. Liberal ou conservador pouco nos importa, contanto que recuse o seu voto ao projecto incendiário do conselheiro Dantas.

Ainda, nesse artigo, vários foram os argumentos que levaram o autor a ser contrário ao projeto abolicionista, proposto por Dantas. Dentre eles, destacamos: a ruína econômica dos proprietários de escravos, pela não indenização e a crise que acometeria a grande lavoura, devido, principalmente, à falta de mão-de-obra, ou porque a imigração, para essas paragens, era impossível, devido ao clima, já que o Sul era mais frio e os que aqui chegavam, no caso os portugueses, não estavam dispostos ao trabalho na lavoura, mas ao comércio, ou ainda, porque o caboclo maranhense era "preguiçoso" e "indolente", amante de um "doce balanço de rede" e sem a mínima disposição para o trabalho de sol a sol.

Expressa com diferentes nomes (indolência/ ociosidade/ pouco amor ao trabalho), a "preguiça" seria fruto da escravidão: as pessoas livres não queriam trabalhar para não serem identificados aos escravos, porque o trabalho manual era considerado "indecoroso" e a prodigalidade da natureza possibilitava a sobrevivência sem grandes esforços. (FARIA, 2004, p.102)

Não entendiam, as elites, que o próprio sistema gerara essa indisposição, na classe dos livres pobres, pois, tendo o escravo para fazer todos os serviços que movimentavam a sociedade da época, aos nativos só restava a mendicância ou o embrenhamento nas matas para de lá tirar o seu sustento. Essa visão preconceituosa da classe dominante constituía-se numa forma de retirar a culpa da ociosidade dos nativos maranhenses dos verdadeiros responsáveis, ou seja, dela própria e do sistema que ela criou, como vemos em Faria (2004, p.102) as elites "[...] tinham dificuldades em aceitar as 
maneiras de viver dos indivíduos pobres [...]. Foi o modelo de colonização que a gerou e marginalizou".

Assim, tentando de todas as formas a manutenção de um sistema já, há muito corroído, em sua base e prestes a ruir, por completo, a classe dominante maranhense mostrava sua mentalidade conservadora e escravocrata, não percebendo ou não querendo perceber a marcha das mudanças que, em breve, operariam a transição do trabalho escravo para o trabalho livre, independente de sua vontade ou de seu apego, o que permaneceu até o fim do processo escravista.

\section{CONSIDERAÇÕES FINAIS}

Procuramos, neste trabalho, traçar um perfil dos personagens que se envolveram na querela sobre o destino do elemento servil, nos momentos finais do regime, analisando suas idéias, seus anseios, interesses e, principalmente, suas motivações para esse envolvimento. Ao encontrarmos os mais diferentes atores envolvidos, percebemos o quanto o desfecho da questão escravista despertava o interesse da sociedade maranhense, mesmo que a maior parte dessa sociedade estivesse alijada do poder e, conseqüentemente, das tomadas de decisões e, talvez, muitos nem viessem a ter acesso direto a tais notícias. Ainda assim, acreditamos que essa discussão envolvia grande parte da população.

Província que tinha no escravo a sua base de sustentação econômica, o Maranhão constituiu-se num dos redutos desse sistema de exploração. Ainda que alguns de seus "vultos" literários tenham protestado contra tal regime e já tendo diminuído, bastante, o contingente de cativos, em relação à primeira metade do século XIX, a idéia de status social que a posse de cativos representava era tão arraigado, entre a maioria dos maranhenses, e a dependência do trabalho escravo tão forte na sociedade, que fora impossível, para a Província, ver-se livre da escravidão antes do 13 de maio de 1888.

O conservadorismo da elite agrária também era outro fator a ser apontado na luta pela manutenção do elemento servil, em cativeiro, até o desfecho do processo. Explica, ainda, a reação violenta que alguns ex-senhores tiveram ao se verem destituídos de sua mão-de-obra, mesmo sendo esse acontecimento já previsto, há quase vinte anos, pois, a 
partir da Lei Rio Branco, a escravidão dava seus últimos suspiros, ainda que no Maranhão os senhores quisessem prolongá-la, indefinidamente.

Desta forma, cremos, ainda, que a assertiva de Conrad (1978: p.154) está de acordo com o que destaca este trabalho.

\begin{abstract}
Na província do Maranhão [...] onde os escravos eram relativamente numerosos e a população de cor era quase o dobro da branca, os cidadãos influentes mostravam-se menos inclinados a soltar as rédeas dos sentimentos abolicionistas. Apesar de menos recalcitrantes do que as províncias do centro-sul, Maranhão e até mesmo a província vizinha do Pará jamais representaram um papel importante no esforço abolicionista, com ambas permanecendo grandes regiões de escravos até às vésperas da abolição.
\end{abstract}

Assim, a Província do Maranhão manteve-se atrelada ao sistema escravista, enquanto este vigorou, sem desenvolver um movimento forte, de combate ao mesmo, embora devamos mencionar que algumas vozes tenham se levantado, protestando contra o cativeiro.

Destacamos, ainda, que os próprios senhores, proprietários de escravos, muitas vezes fantasiavam a real ação dos propagandistas maranhenses, chamando qualquer discurso em favor de uma emancipação lenta e gradual de "abolicionismo revolucionário". Entretanto, tal tipo de abolicionismo foi inexistente no Maranhão, ao menos através da imprensa.

Sendo assim, o que prevaleceu foi o desespero daqueles que não admitiam, em hipótese alguma, abrir mão dos seus escravos que, em dado momento da história maranhense, foram tantos, que o Maranhão ficou conhecido, no século XIX, como o "Baluarte da Escravidão" no país.

\title{
REFERÊNCIAS:
}

\section{FONTES PRIMÁRIAS}

Jornais

Pacotilha - São Luís (1881-1888)

Diário do Maranhão - São Luís (1881-1888)

Paiz (O) - São Luís (1881-1888) 
FONTES SECUNDÁRIAS

ABRANCHES, João Dushee de. O cativeiro. São Luís: Alumar, 1992.

AZEVEDO, Aluisio. O mulato. São Paulo: Ed. Martin Claret, 2002.

BAHIA, Juarez. Jornal, história e técnica: história da imprensa brasileira. 4. ed. São Paulo: Ática, 1990.

BARROS, Luitgarde Cavalcanti. Abolicionismo - ideologia em debate num Ceará precursor. In: SILVA, Jaime da. (org.). Cativeiro e liberdade, UERJ, 1989. p.262-268.

BURNS, Eduard Macnall. História da civilização ocidental. 37. ed. São Paulo: Globo, 1996.

CALDEIRA, José de Ribamar. O Maranhão na literatura dos viajantes. São Luís: AML/SIOGE, 1991.

CAMARGO, Ana Maria de A. A imprensa periódica como fonte para a História do Brasil. In: SIMPÓSIO NACIONAL DE HISTÓRIA, 5., 1971. Portos, rotas e comércio. Brasil, 1971. pp. 225-239.

CAPELATO, Maria Helena R. Imprensa e história do Brasil. São Paulo: Contexto, 1988. (coleção repensando a História).

CARDOSO, Ciro Flamarion S. (org.) Escravidão e abolição no Brasil: novas perspectivas. Rio de Janeiro: Zahar, 1988.

CARVAlHO, José Murilo de. A construção da ordem: a elite política imperial. Teatro de sombras: a política imperial. Rio de Janeiro: Civilização Brasileira, 2003.

CONRAD, Robert. Os últimos anos da escravatura no Brasil (1850-1888). Tradução de Fernando Ferro. 2. ed. Rio de Janeiro: Civilização Brasileira, 1978.

CORREA, Helidacy M. M. Bumba-meu-boi do Maranhão: a construção de uma identidade. 2001. Dissertação (Mestrado em História Cultural). Universidade Federal de Pernambuco. Recife, 2001.

COSTA, Emilia Viotti da. Da senzala à colônia. 3. ed. São Paulo: Brasiliense, 1989.

A abolição. 6. ed. São Paulo: Global, 1997.

FAIRCLOUGH, Norman. Discurso, mudanças e hegemonia. In: PEDRO, E. R. (org.). Análise crítica do discurso. Lisboa: Editorial Caminhos, 1997, pp. 77-103. 
FARIA, Regina Helena M de. Escravos, livres pobres, índios e imigrantes estrangeiros nas representações do Maranhão oitocentista. In: COSTA, Wagner Cabral da (org.). História do Maranhão - novos estudos. São Luís: Edufma, 2004. p. 81-112.

FERREIRA, Luis Alberto. Os clubes republicanos e a implantação da república no Maranhão (1888-1889). In: COSTA, Wagner Cabral da (org.). História do Maranhão novos estudos. São Luís: Edufma, 2004. p. 205-230.

FOUCAULT, Michel. A arqueologia do saber. Tradução Luiz B. Neves. 7. ed. Rio de Janeiro: Forense Universitária, 2004.

GORENDER, Jacob. A escravidão reabilitada. São Paulo: Ática, 1991.

GOUVÊA, Fernando Cruz. Abolição: a liberdade veio do norte. Recife: Massangana, 1988.

GRAF, Márcia Elisa de C. Imprensa periódica e escravidão no Paraná. Curitiba: Secretaria de Estado da Cultura e do Esporte, 1981.

HASENBALG, Carlos A. Discriminação e desigualdades raciais no Brasil. Tradução de Patrick Burglin. Rio de Janeiro: Graal, 1979.

LACROIX, Maria de Lourdes Lauande. A fundação francesa de São Luís e seus mitos. 2. ed. São Luís: Lithograf, 2002.

LUNA, Luiz. O negro na luta contra a escravidão. 2. ed. Rio de Janeiro: Ed. Cátedra, 1976.

MENDONÇA, Joseli Nunes. Cenas da abolição: escravos e senhores no Parlamento e na Justiça. Rio de Janeiro: Ed. Fundação Perseu Abramo, 1999.

MONTELlO, Josué. Aluízio Azevedo e a polêmica do mulato. Rio de Janeiro: Olympio, INL, 1975.

MONTENEGRO, Antonio Torres. Abolição. São Paulo: Ática, 1988. (série Princípios)

MORAES, Evaristo de. A campanha abolicionista (1879-1888). 2. ed. Universidade de Brasília: Brasília, 1986.

MORAES, Nascimento. Vencidos e degenerados: romance. 4. ed. São Luís: Centro Cultural Nascimento Moraes, 2000.

MOURA, Clóvis. Sociologia do negro no Brasil. São Paulo: Ática, 1988.

NICOLAU, Jairo. História do voto no Brasil. Rio de Janeiro: Zahar, 2002.

PRADO JUNIOR, Caio. Formação do Brasil contemporâneo. 16. ed. São Paulo: Brasiliense, 1979. 
QUEIROZ, Suely Robles Reis de. A abolição da escravidão. 5. ed. São Paulo: Brasiliense, 1989. (coleção tudo é História)

Escravidão negra no Brasil. 3. ed. São Paulo: Ática, 1993. (série Princípios)

REIS, João José \& SILVA, Eduardo. Negociação e conflito: a resistência negra no Brasil escravista. São Paulo: Companhia das Letras, 1999.

RIBEIRO, Jalila Ayoub Jorge. A desagregação do sistema escravista no Maranhão (1850-1888). São Luís: SIOGE, 1990.

SCHWARCZ, Lilia M. Retrato em branco e negro: jornais, escravos e cidadãos em São Paulo no final do século XIX. São Paulo: Companhia das Letras, 2001.

SERRA, Joaquim. Sessenta anos de jornalismo: a imprensa no Maranhão 1820-1880. 3. ed. São Paulo: Siciliano, 2001.

VEYNE, Paul Marie. Como se escreve a história. Tradução de Alda Batar e Maria Auxiliadora Kneipp. 2. ed. Brasília: Editora Universidade de Brasília, 1992. 